\title{
EDITORIAL
}

\section{Bibliografia de enfermagem em português}

Uma das grandes dificuldades enfrentadas pelas professoras de enfermagem é o fato de praticamente ser a bibliografia especializada quase toda em inglês.

Algumas editoras e organizações têm-se preocupado com o problema, nestes últimos anos, e promovido traduções quase sempre em espanhol, raramente em português, mas, mesmo assim, a bibliografia em enfermagem accessível a nossos alunos de graduação é paupérrima.

A solução está em produzirmos a nossa própria literatura especializada, o que vem sendo feito em ritmo muito lento. Só recentemente a carreira universitária foi aberta aos enfermeiros, neste País, portanto, só recentemente foram intensificadas as publicações das docentes de enfermagem (Em que pese a reação dos profissionais do sexo masculino, cabe aqui o feminino, pois, a docência de enfermagem exercida por mulheres anda perto dos $100 \%$ ).

Excluídas as revistas especializadas, a grande maioria das publicações de enfermagem, aliás de projeção limitadíssima, está sendo de teses para concursos de doutoramento (USP), Livre Docência e de Professor Titular (Universidades Federais).

E verdade que as revistas de enfermagem, aos poucos, estão-se multiplicando; durante 35 anos, a Revista Brasileira de Enfermagem (no início denominada Anais de Enfermagem) foi a única revista especializada neste País; há pouco tempo, entretanto, três outras foram lançadas: a da Escola de Enfermagem da Universidade de São Paulo, a da Escola de Enfermagem da Universidade Federal do Rio Grande do Sul e Enfermagem em Novas Dimensões, esta de publicação particular.

Em Portugal também são publicadas uma ou duas revistas, mas dificilmente são conseguidas no Brasil; nos países da América La- 
tina, igualmente, há algumas publicações desse tipo, quase inteiramente desconhecidas entre nós.

$\mathrm{O}$ que existe, entretanto, é uma gota dágua no oceano. $\mathrm{O}$ problema da falta de bibliografia de enfermagem ao alcance dos alunos, quer de graduação, quer de nível de $2 .^{\circ}$ grau, continua agudo.

Por esse motivo saudamos com alvíssaras o aparecimento de um livro como ASSOCIAÇÃO BRASILEIRA DE ENFERMAGEM, 1926-1976, DOCUMENTÁRIO, de autoria de Anayde Corrêa de Carvalho. Como o título indica, tem este, como objetivo, documentar as atividades de associação de classe dos enfermeiros, mas como a vida desta Associação está íntima e indissoluvelmente associada à enfermagem do Brasil, é uma verdadeira história da enfermagem brasileira.

"Esta história levou cinqüenta anos para ser vivida e cinco para ser contada" diz a autora ao abrir o Prefácio. De que foram cinco anos de trabalho consciencioso, intenso e contínuo somos testémunha. Mas valeram o esforço, a operosidade e a dedicação de quem o escreveu porque é uma obra profunda, completa e muito bem escrita.

Nas suas 517 páginas encontramos não somente as atividades de uma associação, como também todo um histórico da legislação de enfermagem brasileira, do ensino de nível superior, do ensino de grau médio, da odisséia que foi a criação do Conselho Federal de Enfermagem, das tentativas de sindicalização, dos congressos de enfermagem realizados no País, enfim, de toda uma gama de atividades em que ABEn esteve envolvida e, com ela, a nossa profissão.

Felizes as associações de classe que despertam o interesse de um de seus membros, com as qualidades de paciência, pertinácia e sobretudo competência, para coligir dados em fontes frequentemente precárias, destrinçá-los, estabelecer prioridades e, finalmente, relatá-los clara, correta e fielmente.

A ABEn teve esta felicidade e conta hoje com uma obra de vulto que lhe garante um lugar na posteridade. 